\title{
Association of low serum TGF- $\beta$ level in hantavirus infected patients with severe disease
}

\author{
Mahmoud Sadeghi ${ }^{1}$, Imad Lahdou', Jakob Ettinger ${ }^{2}$, Mojdeh Heidary Navid ${ }^{3}$, Volker Daniel ${ }^{1}$, Martin Zeier ${ }^{4}$, \\ Jörg Hofmann², Gerhard Opelz and Paul Schnitzler ${ }^{3^{*}}$
}

\begin{abstract}
Background: Hantaviruses are emerging zoonotic pathogens which cause hemorrhagic fever with renal syndrome, an immune-mediated pathogenesis is discussed. The aim of the present study was to investigate the role of TGF- $\beta$ expression in acute hantavirus infection.

Results: We retrospectively studied 77 patients hospitalised with acute Puumala infection during a hantavirus epidemic in Germany in 2012. Hantavirus infection was confirmed by positive anti-Puumala hantavirus IgG and IgM. Plasma levels of transforming growth factor (TGF)- $\beta 1$ and TGF- $\beta 2$ were analysed. Based on glomerular filtration rate on admission, patients were divided in mild and severe course of disease. Puumala virus RNA was detected by PCR amplification of the viral $L$ segment gene. Out of 77 Puumala virus infected patients, 52 (68\%) were male. A seasonal distribution was detected in our cohort with a peak in summer 2012, the highest incidence was observed in the age group of 30-39 years. Puumala virus RNA was detectable in 4/77 cases. Patients with severe disease had a significant longer hospital stay than patients with mild disease (6.2 vs 3.6 days). Thrombocyte count (186 vs 225 per $\mathrm{nl}$ ), serum TGF- $\beta 1$ (74 vs $118 \mathrm{ng} / \mathrm{l}$ ) and TGF- $\beta 2$ (479 vs $586 \mathrm{pg} /$ /) were significantly lower in severe compared to mild disease. However, C-reactive protein (CRP) was significantly higher in patients with severe disease (62 vs $40 \mathrm{mg} / \mathrm{l})$. TGF- $\beta 1 / \mathrm{Cr}$ was the most sensitive and specific marker associated with renal dysfunction.
\end{abstract}

Conclusion: High serum CRP and low serum TGF- $\beta$ in the early phase of hantavirus infection is associated with a severe course of disease. Our results support the hypothesis of an immune-mediated pathogenesis in hantavirus infection.

Keywords: Hantavirus, Puumala, Transforming growth factor, TGF, Severe disease

\section{Background}

Three main clinical syndromes can be distinguished after hantavirus infection, i.e. hemorrhagic fever with renal syndrome (HFRS) mainly caused by Seoul, Puumala and Dobrava viruses; nephropathia epidemica, a mild form of HFRS caused by Puumala virus; and hantavirus cardiopulmonary syndrome, which may be caused by Andes virus and Sin Nombre virus. There is no curative treatment for hantavirus infection, and eliminating or minimising contact with rodents is the best way to prevent infection [1]. The case fatality rate of HFRS varies from $<1 \%$ to $12 \%$ depending on the virus type [2]. Over 50 000 nephropathia epidemica cases with Puumala virus infections have been registered in Europe, and even over

\footnotetext{
* Correspondence: paul.schnitzler@med.uni-heidelberg.de

${ }^{3}$ Department of Infectious Diseases, Virology, University of Heidelberg, Im

Neuenheimer Feld 324, 69120 Heidelberg, Germany

Full list of author information is available at the end of the article
}

175000 in Western Russia [3]. Approximately 150,000 to 200,000 humans are hospitalized each year because of hantavirus infections worldwide [2]. European hantaviruses of the family Bunyaviridae cause HFRS. Infection in humans occurs through inhalation of aerosolised virus particles from excreta of chronically infected wild rodents [4]. Puumala is reported throughout most of Europe (excluding the Mediterranean region) wheras Dobrava, carried by the yellow-necked mouse (Apodemus flavicollis) and Saaremaa, carried by the striped field mouse (Apodemus agrarius), are reported mainly in eastern and central Europe [5]. In Germany, several hantaviruses pathogenic for humans are circulating, i.e. Puumala virus, Dobrava virus and Tula virus [6,7]. Puumala virus is carried by the bank vole (Clethrionomys glareolus) and leads mostly to a mild form of disease [3].

The course of HFRS is highly variable, ranging from frequently asymptomatic to a lethal outcome. Host genetic 
factors influence the clinical outcome. The most common symptoms are high fever, headache, abdominal pain, backache and nausea or vomiting. Proteinuria, haematuria and acute kidney injury are signs of renal involvement. Classically, HFRS occurs in five distinct phases: febrile, hypotensive, oliguric, polyuric and convalescent [8]. A severe course of disease comprises oliguria, high blood creatinine and a high leukocyte count [9], the disease severity depends on the hantavirus genotype. A minority of patients needs transient dialysis treatment, but complete recovery is the usual outcome $[10,11]$. Outinen et al. defined the severity of hantavirus infection by serum creatinine and thrombocytes count [12]. The role of immune response and cytokine expression during Puumala virus infection has been described previously [13,14]. Techniques for the identification of novel hantaviruses by specific cell culture models had been established [15]. Only few cases of Puumala virus infection with severe disease had been reported for Germany recently [16,17].

In the year 2012, the highest number of human hantavirus infections were observed and more than 2800 cases were reported, $30 \%$ of these infections were located in Southwestern Germany. Case numbers started to rise earlier during the year than had been reported in previous epidemics in 2007 and 2010, and are the largest ever reported in this region $[18,19]$. The early rise might be associated with a birch mast year in 2011, followed by an early and massive reproduction of the reservoir of bank vole populations during winter 2011 and spring 2012 [20]. However, a possible influence of climate change on the survival, emergence and epidemiology of hantaviruses is difficult to predict [21].

It has been suggested that viral load and immunological factors including cytokines are involved in the pathogenesis of Puumala virus infection. The extent and level of viremia depends largely on the hantavirus type, viral load is considerably lower in HFRS caused by Puumala virus when compared to other hantaviruses. Thus viral load clearly plays a role in disease pathogenesis [8]. In a recent study, patients infected with Dobrava virus were found to have a higher viral load than Puumala infected patients [13]. The aim of this study was to analyse TGF- $ß$ serum levels in patients with hantavirus infection and to evaluate the level of TGF- $\beta$ in mild and severe course of disease.

\section{Results}

\section{Patient characteristics and clinical findings}

On admission, all study patients were seropositive for anti-Puumala IgG and IgM antibodies. Out of 77 patients with acute Puumala virus infection, 52 (68\%) were male. A seasonal distribution of hantavirus infection was detected in our cohort and for nationwide cases with a peak in summer 2012. Age distribution showed a higher percentage of patients in the age groups of $20-39$ (48.1\% vs $33.1 \%$; $\mathrm{p}<0.05)$ years and a lower percentage of patients in the age groups of $40-59$ (32.5\% vs $48.0 \%$; $\mathrm{p}<0.05)$ years in our cohort compared to nationwide data (Figure 1). In contrast to the highest incidence in the age group of $40-49(28.1 \%$ vs $15.6 \%$; $\mathrm{p}<0.05)$ years nationwide, our study patients demonstrated the highest proportion in the age group of 30-39 years $(24.7 \%$ vs $18.0 \%$; $>0.05$, not significant).

For all patients mean hospitalization time was 4.9 days. On admission, demographic data and clinical symptoms such as fever, myalgia, and headache were similar in patients with mild and severe disease (Table 1). However, patients with a severe course of disease defined by a glomerular filtration rate (GFR) of $<30 \mathrm{ml} / \mathrm{min}$ had significantly longer hospital stay (6.2 vs 3.6 days) and significantly higher proteinuria levels ( 1.3 vs $0.6 \mathrm{~g} / \mathrm{l})$ compared to patients with mild disease, respectively. The most common symptoms reported on admission were myalgia, fever, headache, shivering, low back pain, and arthralgia (Table 1). All patients had impaired renal function to some degree on admission with an increase in retention parameters over the course of disease, six patients (8\%) required intermittent hemodialysis.

\section{Correlation of cytokine expression with disease severity}

On admission, CRP was increased (62 vs $40 \mathrm{mg} / \mathrm{l}$ ), a similar finding was observed for creatinine (5.6 vs. 2.4) in patients with severe and mild disease, respectively. Interestingly, patients with severe disease had significantly lower TGF- $\beta 1$ and TGF- $\beta 2$ serum levels than patients with mild disease, suggesting an association of TGF- 31 and TGF- 32 with disease severity (Table 2). All patients had non-detectable TGF- $\beta 3$ serum levels. The course of cytokine levels for TGF- 11 , TGF- 32 , as well as CRP and thrombocyte count on admission and one week after admission to the hospital is shown in Figure 2 and Table 3. TGF- $\beta 1$ and TGF- $ß 2$ concentrations on admission imply a stronger TGF- $ß 1$ and TGF- 32 production in patients with severe than in patients with mild disease (Figure 2). Both patient groups had similar CRP level and thrombocyte count one week after admission. Creatinine remained significantly higher in patients with severe disease during follow-up (data not shown). ROC curve analysis was performed for TGF- $\beta 1$, TGF- $\beta 2$ as well as for TGF- $\beta 1 / \mathrm{Cr}$ and TGF- $\beta 2 / \mathrm{Cr}$ ratios on admission. TGF- $\beta 1 / \mathrm{Cr}$ ratio showed the best association with severe disease, followed by TGF- $\beta 1 / \mathrm{Cr}$ ratio (Figure 3).

\section{Phylogenetic analysis of puumala virus}

For phylogenetic analysis, samples positive for hantavirus RNA were sequenced in the hantavirus S-segment. The data revealed no unique hantavirus strain in these patients. The sequence data indicate a heterogeneous strain reservoir in Southwest Germany, some hantavirus 

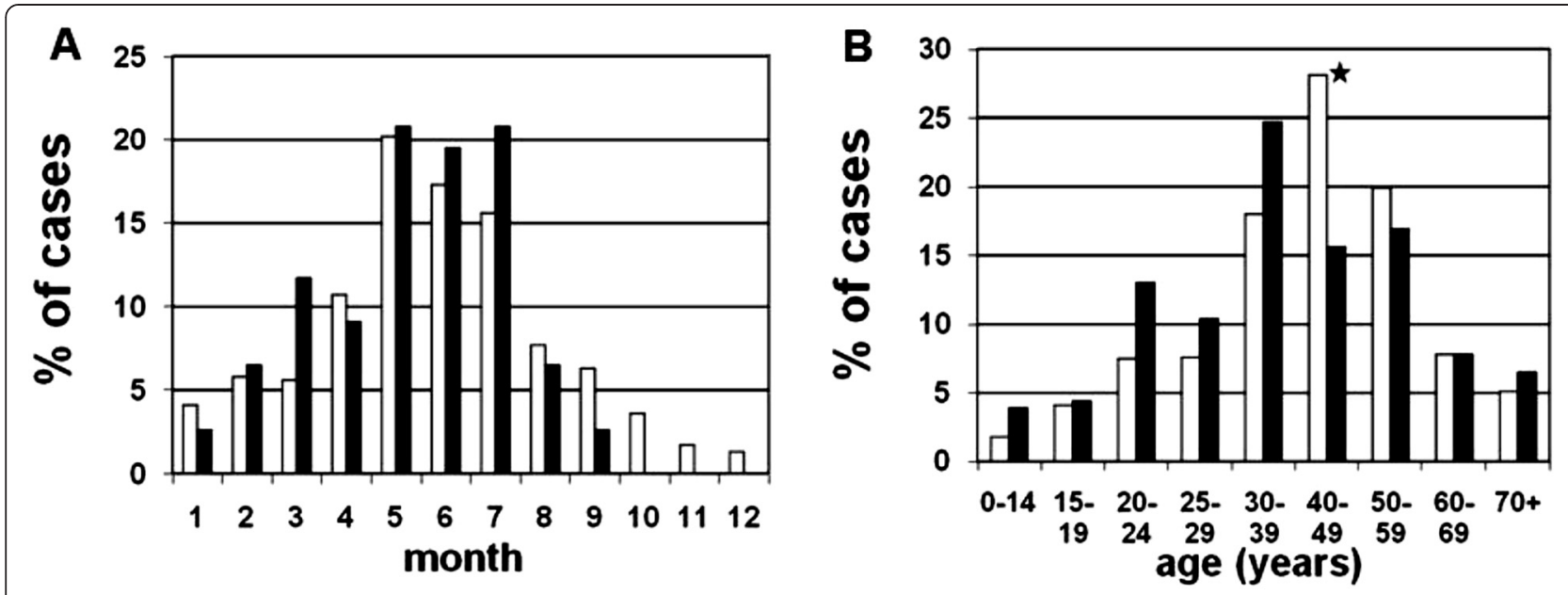

\section{Germany}

Study group

Figure 1 Seasonality (A) and age distribution (B) of hantavirus infections in Germany (white bars) and our study cohort (black bars).

strains showed the highest relatedness to strains from the Spessart forest or the Bavarian forest (Figure 4).

\section{Discussion}

Pathogenesis of hantavirus is not well understood, but most likely virus-mediated, host-mediated mechanisms

Table 1 Clinical data of Puumala virus infected patients with mild and severe disease on admission

\begin{tabular}{llll}
\hline Parameters & $\begin{array}{l}\text { Mild disease } \\
(\mathbf{n = 3 8})\end{array}$ & $\begin{array}{l}\text { Severe disease } \\
(\mathbf{n}=\mathbf{3 9})\end{array}$ & p-value \\
\hline age in years (mean \pm SD) & $39.2 \pm 15.5$ & $42.7 \pm 16.9$ & 0.34 \\
male & $63.2 \%$ & $71.8 \%$ & 0.42 \\
hospital stay (days \pm SD) & $3.6 \pm 3.6$ & $6.2 \pm 3.4$ & 0.001 \\
myalgia & $87 \%$ & $87 \%$ & 0.69 \\
fever & $84 \%$ & $82 \%$ & 0.80 \\
headache & $84 \%$ & $82 \%$ & 0.80 \\
shivering & $82 \%$ & $80 \%$ & 0.82 \\
low back pain & $82 \%$ & $74 \%$ & 0.45 \\
arthralgia & $71 \%$ & $87 \%$ & 0.27 \\
stomach ache & $63 \%$ & $56 \%$ & 0.74 \\
nausea & $58 \%$ & $54 \%$ & 0.72 \\
vomiting & $42 \%$ & $33 \%)$ & 0.43 \\
diarrhea & $18 \%$ & $10 \%$ & 0.31 \\
vision disturbance & $11 \%$ & $15 \%$ & 0.53 \\
dyspnoea & $13 \%$ & $10 \%$ & 0.69 \\
thrombocytes min. (/nl \pm SD) & $206 \pm 131$ & $177 \pm 115$ & 0.48 \\
proteinuria (g/l \pm SD) & $0.6 \pm 1.5$ & $1.3 \pm 2.3$ & 0.009 \\
\hline Symptoms are show in $\%$ of & &
\end{tabular}

Symptoms are shown in \% of patients. as well as viral load are involved [22]. Most European and Asian cases of hantavirus infection are characterized by acute renal failure, thrombocytopenia and increased vascular permeability [19]. Acute renal failure is observed in $90-95 \%$ of infections with Old World hantaviruses. The long-term prognosis of nephropathia epidemica (NE) caused by Puumala virus is favorable and most patients fully recover renal function [19].

Several previous studies reported an association of pro-inflammatory cytokines and severity of hantavirus infections [14,23-26]. There are only few reports about the role of anti-inflammatory and suppressive cytokines such as TGF- $\beta$ in hantavirus infection. Temonen et al.

Table 2 Laboratory data and cytokine analysis of patients with mild and severe disease on admission

\begin{tabular}{|c|c|c|c|}
\hline Parameters & $\begin{array}{l}\text { Mild disease } \\
(n=38)\end{array}$ & $\begin{array}{l}\text { Severe disease } \\
(n=39)\end{array}$ & p-value \\
\hline creatinine (mg/dl) & $2.41 \pm 1.9$ & $5.6 \pm 2.6$ & $<0.0001$ \\
\hline leukocyte (/nl) & $8.6 \pm 2.6$ & $9.6 \pm 3.7$ & 0.55 \\
\hline thrombocytes (/nl) & $342 \pm 156$ & $232 \pm 136$ & $<0.0001$ \\
\hline CRP (mg/l) & $40 \pm 36$ & $62 \pm 45$ & $<0.0001$ \\
\hline TGF- $\beta 1$ (ng/ml) & $118 \pm 47$ & $74 \pm 28$ & 0.0001 \\
\hline $\mathrm{TGF}-\beta 1 / \mathrm{Cr}$ & $76 \pm 60$ & $17 \pm 10$ & $<0.0001$ \\
\hline TGF- $\beta 2$ (pg/ml) & $586 \pm 155$ & $479 \pm 146$ & 0.004 \\
\hline $\mathrm{TGF}-\beta 2 / \mathrm{Cr}$ & $384 \pm 283$ & $110 \pm 68$ & $<0.0001$ \\
\hline sCD30 (U/ml) & $104 \pm 63$ & $126 \pm 71$ & 0.17 \\
\hline $\mathrm{sCD} 30 / \mathrm{Cr}$ & $60 \pm 48$ & $29 \pm 29$ & 0.0002 \\
\hline neopterin $(\mathrm{nmol} / \mathrm{l})$ & $172 \pm 246$ & $186 \pm 227$ & 0.41 \\
\hline neopterin/Cr & $70 \pm 99$ & $36 \pm 37$ & 0.04 \\
\hline
\end{tabular}



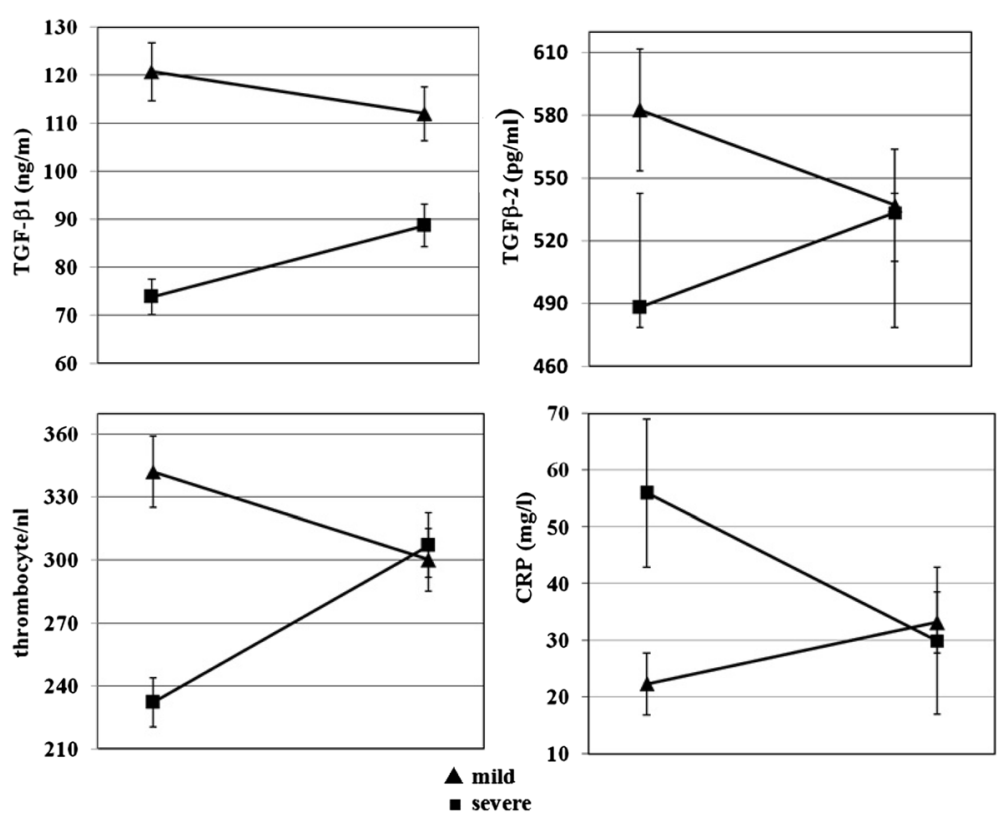

Figure 2 Serum TGF- $\beta 1$, TGF- $\beta 2$ concentration, thrombocyte count and CRP in patients with mild or severe Puumala virus infection. Values are given for the time on admission and one week after admission.

investigated kidney biopsies of patients with nephropathia epidemica and described an increased expression of the cytokines TNF- $\alpha$, TGF- $\beta$, and platelet-derived growth factormainly in the peritubular area of the distal nephron. Concomitantly also at the same location expression of the endothelial adhesion molecules ICAM-1, VCAM, and PECAM was seen [27]. Similarly, it was shown in a more recent study of deer mice infected with Sin Nombre virus, that TGF- $\beta 1$ expressing regulatory $\mathrm{T}$ cells may play an important role in limiting immunopathology in the natural reservoir host, but this response may interfere with viral clearance [28]. In a previous study it was shown that disease severity characterized by elevated creatinine and low platelet counts was correlated with high pro-inflammatory IL- 6 and TNF- $\alpha$ but low immunosuppressive TGF- $\beta 1$ levels and vice versa,

Table 3 Mean and median serum values of TGF- $\beta 1$, TGF- $\beta 2$, and TGF- $\beta / \mathrm{Cr}$ ratios

\begin{tabular}{|c|c|c|c|}
\hline TGF- $\beta$ & $\begin{array}{l}\text { Acute phase } \\
(n=39)\end{array}$ & $\begin{array}{l}\text { One week } \\
\text { follow-up }(n=29)\end{array}$ & $\overline{p \text {-value }}$ \\
\hline TGF- $\beta 1$ (ng/ml; mean \pm SD) & $74 \pm 28$ & $89 \pm 39$ & 0.020 \\
\hline TGF- $\beta 1$ (ng/ml; median) & 74 & 86 & 0.020 \\
\hline TGF- $\beta 2$ (pg/ml; mean \pm SD) & $479 \pm 146$ & $533 \pm 118$ & 0.008 \\
\hline TGF-ß2 (pg/ml; median) & 488 & 534 & 0.008 \\
\hline TGF- $\beta 1 / C r($ mean \pm SD) & $17 \pm 10$ & $37 \pm 40$ & 0.020 \\
\hline TGF- $\beta 1 / C r$ (median) & 13 & 22 & 0.020 \\
\hline $\mathrm{TGF}-\beta 2 / \mathrm{Cr}($ mean $\pm \mathrm{SD})$ & $110 \pm 68$ & $212 \pm 197$ & 0.008 \\
\hline TGF- $\beta 2 / C r$ (median) & 88 & 117 & 0.008 \\
\hline
\end{tabular}

Cr: creatinine suggesting the induction of a protective immune mechanism to downregulate or even prevent a massive pro-inflammatory immune response [14]. Klempa et al. described mild and severe cases of hemorrhagic fever with renal syndrome in patients infected with DobravaBelgrade virus in Russia [29]. In accordance with our results, they found a high number of patients with headache in severe hantavirus infection and elevated creatinine in severe course of the disease. In the current

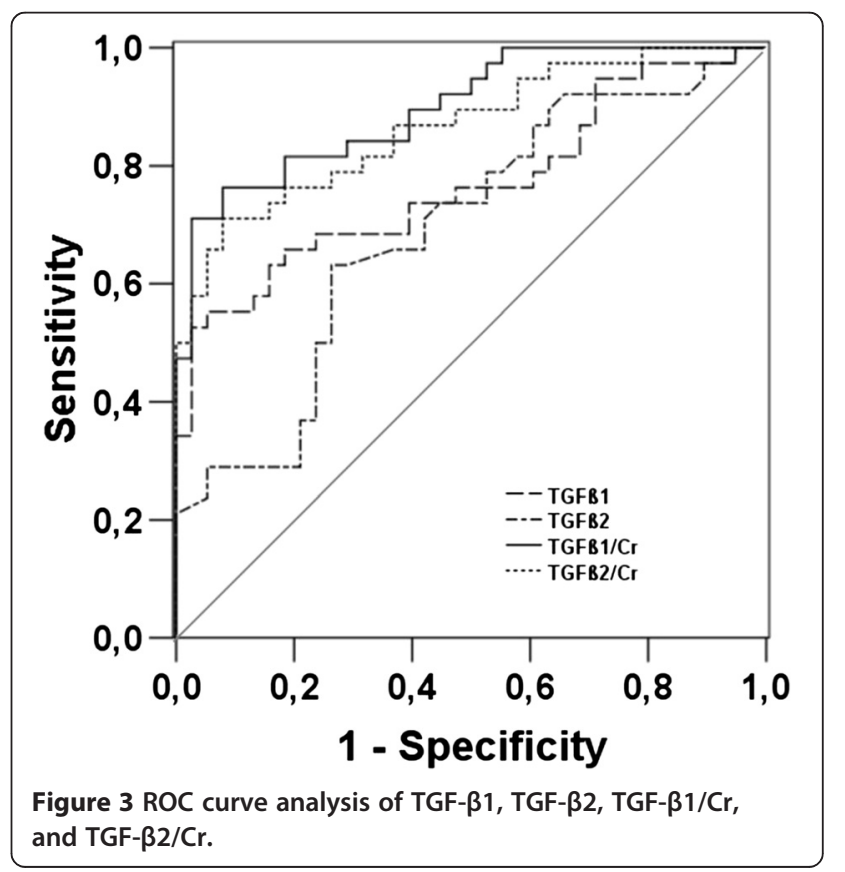




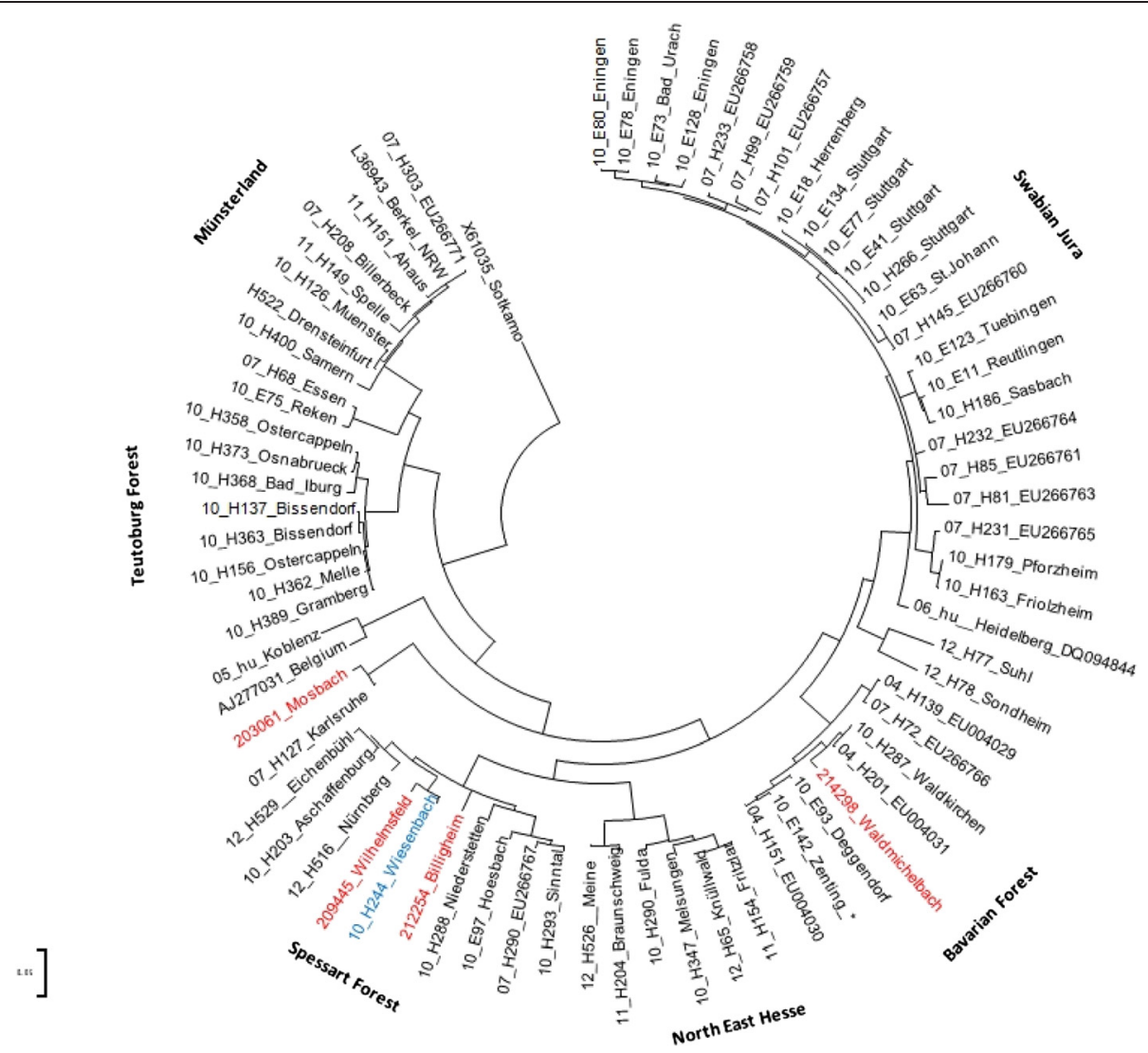

Figure 4 Neighbor-joining phylogenetic tree (TN93 evolutionary model) of human Puumala virus (PUUV) strains based on partial sequences of the S segment (504 nt, position 392-894). PUUV-sequence from strain Sotkamo was used as an outgroup. Sequences taken from GenBank are indicated by their accession numbers. The numbers 04 to 12 in front of the sample names indicate the year (2004-2012) when the sample was collected. Four sequences obtained in this study are colored in red (acc.-no.: KM013472-KM013475) and an additional sample (in blue) was published in an earlier study [Reference PMID: 22958255]. Phylogenetic clades are described earlier [Reference PMID: 22932394]. Scale bar indicates an evolutionary distance of 0.1 substitutions per position.

study, we were able to illustrate the role of TGF- $\beta 1$ and TGF- 32 as major protective markers of hantavirus infection. With increased production in patients with severe disease as a response to inflammation [30,31], TGF- $\beta 1$ and TGF- $\beta 2$ serum levels reached similar levels in both patient groups one week after admission. Obviously, patients with severe disease generate TGF- $\beta$ delayed compared to patients with mild disease allowing stronger proinflammatory cytokine responses and inflammation in these patients.

TGF- $\beta$ has a pivotal function in the immune system and controls the initiation and resolution of inflammatory responses through the regulation of chemotaxis, activation, and survival of lymphocytes, natural killer cells, dendritic cells, macrophages, mast cells, and granulocytes [32]. There are reports of increased TGF- $\beta$ during many viral infections, such as influenza, HIV, hepatitis B virus and hepatitis $C$ virus infection. The neuraminidase glycoprotein of influenza $\mathrm{A}$ and $\mathrm{B}$ viruses have been shown to directly activate latent TGF- $\beta$ [32]. Prognostic and predictive values of TGF- $\beta$ in acute viral infections have not been studied.

In a macaques model of hantavirus infection, Sironen et al. showed that viral RNA was observed in kidney, spleen and liver tissues. Inflammatory cell infiltrations and tubular damage were found in the kidneys, and these infiltrations contained mainly CD8 T-cells [33]. As reported by Rook et al., TGF- $\beta$ exerts profound inhibitory effects on $\mathrm{T}$ and $\mathrm{B}$ lymphocyte proliferation [34]. $\mathrm{T}$ regulatory (Treg)- and $\mathrm{T}$ suppressor (Ts)-mediated immunosuppression appears to depend on two pathways: cell-cell contact and cytokine secretion, whereby cytokine secretion is assumed to be more important. Intracellular cytokines, such as interferon (IFN)- $\gamma$, IL-10 and TGF- $\beta$ are characteristic for certain Treg subsets and are related with induced Treg function. Stimulation by mitogens significantly induce TGF- $\beta^{+}$-Treg and -Ts. Tregs are an important component in regulating the magnitude of the immune response to infection, thus preventing excessive inflammation and tissue damage 
[35]. In previous studies it was suggested that IFN- $\gamma-$ secreting Treg are forming the first line of immunoregulatory $\mathrm{T}$ cells during an initiated immune response, followed by $\mathrm{IL}-2^{-}$, IL- $10^{+}$, or TGF- $\beta^{+}$Treg. Thus, high serum levels of TGF- $\beta$ s during the acute phase and convalescence period of hantavirus infection might be a protective parameter against pro-inflammatory cytokines and endothelial injury. We found a positive correlation of both TGF- $\beta$ s with platelet counts and GFR. In contrast to TGF- $\beta \mathrm{s}$, serum sCD30 and neopterin showed no significant correlation with main symptoms of disease.

Analysis of cytokines responses during the acute phase in our studied patients revealed a significant difference between patients with mild and severe disease. We showed associations of serum TGF- $\beta$ s and TGF- $\beta$ s $/ \mathrm{Cr}$ ratios during the acute phase of hantavirus infection with GFR and disease severity. Severe anti-inflammatory response was associated with relatively mild disease whereas weak reactions were associated with severe renal failure. These data suggest that plasma TGF- $\beta \mathrm{s}$ levels and especially TGF- $\beta$ s/Cr ratios during the acute phase of hantavirus infections may serve as a determining factor of disease severity that allow prediction of disease severity.

CRP is an acute phase protein, and during acute phase of NE, an increase in the serum CRP concentration is a typical laboratory finding [12]. The known main functions of CRP are complement activation, enhancement of phagocytosis, and induction of cytokine synthesis. Although the CRP level is widely used as an indicator of the severity of the disease in various infections, there are no reports associating high CRP levels with severe disease in $\mathrm{NE}$ or other viral infections. Outinen et al. showed that high plasma IL-6 concentrations are associated with a clinically severe acute Puumala hantavirus infection, whereas, high plasma CRP as such does not reflect the severity of the disease [12]. However, in the present study serum CRP was a hallmark of kidney injury.

In order to analyse a relationship of these findings to a distinct hantavirus genotype circulating in the Heidelberg area, phylogenetic analysis of hantavirus strains was performed. The data revealed no unique hantavirus strain in these patients and indicate a heterogeneous strain reservoir in Southwest Germany. Some hantavirus strains showed the highest relatedness to strains from the Spessart forest or the Bavarian forest and none of the sequenced strains was similar to the Heidelberg strain published previously.

\section{Conclusions}

We conclude that measurement of TGF- $\beta$ s and especially TGF- $\beta$ s/Cr ratios in the early phase of Puumala hantavirus infection are very sensitive markers of kidney damage and that high expression of TGF- $\beta 1$ and TGF- $\beta 2$ are associated with milder courses of hantavirus infection. High CRP is a marker of disease severity in hantavirus infection. Our results support the hypothesis of an immunemediated pathogenesis of hantavirus infection.

\section{Methods}

\section{Study population}

In this retrospective study, we analyzed clinical and laboratory data of 77 hospitalised patients diagnosed with acute hantavirus infection at the University Hospital Heidelberg. Glomerular filtration rate (GFR) provides the best index of overall kidney function and creatinine concentration is the most widely used parameter for estimation of GFR [8]. Based on GFR, we divided patients into two groups: patients with mild disease (GFR $\geq 30 \mathrm{ml} / \mathrm{min}$ ) and patients with severe disease (GFR $<30 \mathrm{ml} / \mathrm{min})$. The first blood sample of each patient was obtained on admission to the hospital, on average 7 days after onset of symptoms. An additional blood sample was obtained one week after admission. All samples were analysed for cytokine and lymphocyte, monocyte/macrophage activating and inflammatory marker expression including transforming growth factor (TGF)- $\beta 1,-\beta 2,-\beta 3, \mathrm{sCD} 30$ and neopterin levels. The mean age of patients was 40.8 years, 52 were male (68\%), five (6\%) were under the age of 18 years.

\section{Detection of hantavirus antibodies and RNA}

Sera were tested for hantavirus IgG and IgM antibodies using the recomLine hantavirus assay (Mikrogen, Munich, Germany), coated with specific hantavirus nucleocapsid antigens of Puumala virus, Dobrava-Belgrade virus, Hantaan virus and Seoul virus. Patients were included in the study if both, hantavirus IgG and IgM were positive. Positive results of IgG and negative results of IgM for hantavirus may also indicate an infection with mild clinical symptoms. However, for these patients with positive IgG and negative IgM for hantavirus, reference samples were available indicating no acute but past hantavirus infection. Consequently, these patients had been excluded from the study. PCR for the detection of hantavirus RNA was performed on the L-segment [36]. For phylogenetic analysis positive samples were subsequently sequenced in the S-segment [18]. Characteristics of the sequence analysis are given in the legend to the figure.

\section{Determination of serum cytokines and CRP}

TGF- $\beta 1, \beta 2$ and $\beta 3$ were measured with the Luminex TGF assay (R\&D Systems, Wiesbaden, Germany). To exclude cytokine accumulation due to dysfunction of renal excretion, cytokine/creatinine ratios were calculated. For ease of viewing, TGF- $\beta 1$ is shown in $\mathrm{ng} / \mathrm{ml}$, whereas TGF$\beta 2$ and TGF- $\beta 3$ are shown in $\mathrm{pg} / \mathrm{ml}$. Serum neopterin was measured with the Neopterin ELISA kit (Brahms, Berlin, Germany). Based on control measurements in 36 healthy 
individuals, neopterin concentrations $>15 \mathrm{nmol} / \mathrm{l}$ is considered above normal range. Sera were tested for serum sCD30 content using a commercially available ELISA kit (Bender MedSystems, Vienna, Austria). All cytokines, neopterin and CRP were determined on admission of the patients to the hospital and one week after admission.

\section{Statistical analysis}

Categorical and continuous variables were analyzed using chi square, Fisher exact and Mann-Whitney-U tests. Statistical analyses were performed with the Statistical Package for the Social Sciences (SPSS, 18.0). After Bonferroni correction, $\mathrm{p}$ values $\leq 0.05$ were considered statistically significant.

\section{Ethical approval}

This study was approved by the Ethics Committee of the Faculty of Medicine, University Heidelberg. Written consent was obtained from patients.

\section{Competing interests}

The authors declare that they have no competing interests.

\section{Authors' contributions}

MS, VD and PS developed the design of the study. MS, MHN and IL carried out the immunoassays for cytokine analysis. JE and JH performed PCR and sequencing on hantavirus RNA. VD, GO and PS drafted the manuscript. All authors read and approved the final manuscript.

\section{Acknowledgement}

We thank the Förderverein zur Bekämpfung der Viruskrankheiten for financial support.

\section{Author details \\ 'Department of Transplantation Immunology, University of Heidelberg, Im Neuenheimer Feld 305, 69120 Heidelberg, Germany. ${ }^{2}$ Institute of Medical Virology, Charité University Medicine Berlin, Charitéplatz 1, 10117 Berlin, Germany. ${ }^{3}$ Department of Infectious Diseases, Virology, University of Heidelberg, Im Neuenheimer Feld 324, 69120 Heidelberg, Germany. ${ }^{4}$ Department of Nephrology, University of Heidelberg, Im Neuenheimer Feld 162, 69120 Heidelberg, Germany.}

Received: 23 November 2014 Accepted: 16 March 2015 Published online: 14 April 2015

\section{References}

1. European Center for Disease Prevention and Control, www.ecdc.europa.eu.

2. Bi Z, Formenty PB, Roth CE. Hantavirus infection: a review and global update. J Infect Dev Ctries. 2008;2:3

3. Clement J, Maes P, Lagrou K, Van Ranst M, Lameire N. A unifying hypothesis and a single name for a complex globally emerging infection: hantavirus disease. Eur J Clin Microbiol Infect Dis. 2012;31:1-5.

4. Faber MS, Ulrich RG, Frank C, Brockmann SO, Pfaff GM, Jacob J, et al. Steep rise in notified hantavirus infections in Germany, April 2010. Euro Surveill 2010; 15: pii = 19574 .

5. Vapalahti O, Mustonen J, Lundkvist A, Henttonen H, Plyusnin A, Vaheri A. Hantavirus infections in Europe. Lancet Infect Dis. 2003;3:653-61.

6. Hofmann J, Meier M, Enders M, Führer A, Ettinger J, Klempa B, et al. Hantavirus disease in Germany due to infection with Dobrava-Belgrade virus genotype Kurkino. Clin Microbiol Infect. 2014;20:648-55.

7. Mertens M, Hofmann J, Petraityte-Burneikiene R, Ziller M, Sasnaukas K, Friedrich $\mathrm{R}$, et al. Seroprevalence study in forestry workers of a non-endemic region in eastern Germany reveals infections by Tula and Dobrava-Belgrade hantaviruses. Med Microbiol Immunol. 2011;200:263-8.
8. Vaheri A, Strandin T, Hepojoki J, Sironen T, Henttonen H, Mäkelä S, et al. Uncovering the mysteries of hantavirus infections. Nat Rev. 2013;11:539-50.

9. Lee HW, van der Groen G. Hemorrhagic fever with renal syndrome. Prog Med Virol. 1989:36:62-102.

10. Krüger DH, Schönrich $G$, Klempa B. Human pathogenic hantaviruses and prevention of infection. Hum Vacc. 2011;7:685-93.

11. Kanerva M, Mustonen J, Vaheri A. Pathogenesis of puumala and other hantavirus infections. Rev Med Virol. 1998;8:67.

12. Outinen TK, Makela SM, Ala-Houhala IO, Huhtala HS, Hurme M, Paakkala AS, et al. The severity of Puumala hantavirus induced nephropathia epidemica can be better evaluated using plasma interleukin-6 than C-reactive protein determinations. BMC Infect Dis. 2010;10:132.

13. Korva M, Saksida A, Kejzar N, Schmaljohn C, Avsic-Zupanc T. Viral load and immune response dynamics in patients with haemorrhagic fever with renal syndrome. Clin Microbiol Infect. 2013;19:358-66.

14. Sadeghi M, Eckerle I, Daniel V, Burkhardt U, Opelz G, Schnitzler P. Cytokine expression during early and late phase of acute Puumala hantavirus infection. BMC Immunol. 2011;12:65

15. Eckerle I, Lenk $M$, Ulrich RG. More novel hantaviruses and diversifying reservoir hosts - time for development of reservoir-derived cell culture models? Viruses. 2014:6:951-67.

16. Eckerle I, Jakob E, Hofmann J, Schmidt-Bacher A, Ettinger J, Schnitzler P. Atypical severe Puumala hantavirus infection and virus sequence analysis of the patient and regional reservoir host. Zoonoses Publ Health. 2012;59:110-5.

17. Steiner T, Ettinger J, Peng Z, Hofmann J, Hartmann M, Burkhardt U, et al. Hyperintense lesion in the corpus callosum associated with Puumala hantavirus infection. J Neurol. 2012;259:1742-5.

18. Hofmann J, Meisel H, Klempa B, Vesenbeckh SM, Beck R, Michel D, et al. Hantavirus outbreak, Germany, 2007. Emerg Infect Dis. 2008;14:850-2.

19. Krautkrämer E, Zeier M, Plyusnin A. Hantavirus infection: an emerging infectious disease causing acute renal failure. Kidney Int. 2013;83:23.

20. Boone I, Wagner-Wiening C, Reil D, Jacob J, Rosenfeld UM, Ulrich RG, et al., Rise in the number of notified human hantavirus infections since October 2011 in Baden-Wurttemberg, Germany. Euro Surveill. 2012; 17: pii = 20180.

21. Klempa B. Hantaviruses and climate change. Clin Microbiol Infect. 2009;15:518-23.

22. Pettersson L, Thunberg T, Rocklov J, Klingstrom J, Evander M, AhIm C. Viral load and humoral immune response in association with disease severity in Puumala hantavirus-infected patients-implications for treatment. Clin Microbiol Infect. 2014:20:235-41.

23. Fan W, Liu X, Yue J. Determination of urine tumor necrosis factor, IL-6, IL-8, and serum IL-6 in patients with hemorrhagic fever with renal syndrome. Braz J Infect Dis. 2012;16:527.

24. Libraty DH, Makela S, VIk J, Hurme M, Vaheri A, Ennis FA, et al. The degree of leukocytosis and urine GATA-3 mRNA levels are risk factors for severe acute kidney injury in Puumala virus nephropathia epidemica. PLoS One. 2012; 7:e35402

25. Saksida A, Wraber B, Avsic-Zupanc T. Serum levels of inflammatory and regulatory cytokines in patients with hemorrhagic fever with renal syndrome. BMC Infect Dis. 2011;11:142.

26. Peters CJ, Simpson GL, Levy H. Spectrum of hantavirus infection: hemorrhagic fever with renal syndrome and hantavirus pulmonary syndrome. Annu Rev Med. 1999:50:531.

27. Temonen M, Mustonen J, Helin H, Pasternack A, Vaheri A, Holthöfer H. Cytokines, adhesion molecules, and cellular infiltration in nephropathia kidneys: an immunohistochemical study. Clin Immunol Immunopathol. 1996;78:47-55

28. Schountz T, Prescott J, Cogswell AC, Oko L, Mirowsky-Garcia K, Galvez AP, et al. Regulatory T cell-like responses in deer mice persistently infected with Sin Nombre virus. Proc Natl Acad Sci U S A. 2007:104:15496-501.

29. Klempa B, Tkachenko EA, Dzagurova TK, Yunicheva W, Morozov VG, Okulova NM, et al. Hemorrhagic fever with renal syndrome caused by 2 lineages of Dobrava hantavirus, Russia. Emerg Infect Dis. 2008;14:617-25.

30. Tran DQ. TGF-beta: the sword, the wand, and the shield of FOXP3(+) regulatory T cells. J Mol Cell Biol. 2012;4:29.

31. Galliera E, Corsi MM, Banfi G. Platelet rich plasma therapy: inflammatory molecules involved in tissue healing. J Biol Regul Homeost Agents. 2012;26:35.

32. Li MO, Wan YY, Sanjabi S, Robertson AK, Flavell RA. Transforming growth factor-beta regulation of immune responses. Annu Rev Immunol. 2006;24:99. 
33. Sironen T, Klingstrom J, Vaheri A, Andersson LC, Lundkvist A, Plyusnin A. Pathology of Puumala hantavirus infection in macaques. PLoS One. 2008;: $:$ e3035.

34. Rook AH, Kehrl JH, Wakefield LM, Roberts AB, Sporn MB, Burlington DB, et al. Effects of transforming growth factor beta on the functions of natural killer cells: depressed cytolytic activity and blunting of interferon responsiveness. J Immunol. 1986;136:3916.

35. Cecere TE, Todd SM, Leroith $T$. Regulatory $T$ cells in arterivirus and coronavirus infections: do they protect against disease or enhance it? Viruses. 2012;4:833

36. Kramski M, Meisel H, Klempa B, Krüger DH, Pauli G, Nitsche A. Detection and typing of human pathogenic hantaviruses by real-time reverse transcription-PCR and pyrosequencing. Clin Chem. 2007;53:11.

\section{Submit your next manuscript to BioMed Central and take full advantage of:}

- Convenient online submission

- Thorough peer review

- No space constraints or color figure charges

- Immediate publication on acceptance

- Inclusion in PubMed, CAS, Scopus and Google Scholar

- Research which is freely available for redistribution 